Article

\title{
The Effect of Supplementing Conventional Instruction with Facebook on the Achievement of Pre-Service Integrated Science Teachers in Organic Chemistry in, Abeokuta, Ogun State
}

\author{
Nathaniel Ayodeji OMILANI \\ Department of Science and Technology Education, University of Ibadan, Nigeria \\ *Correspondence: ayonath2002@gmail.com
}

How to cite this paper: Ayodeji OMILANI, N. (2021). The Effect of Supplementing Conventional Instruction with Facebook on the Achievement of Pre-Service Integrated Science Teachers in Organic Chemistry in, Abeokuta, Ogun State. Open Journal of Educational Research, 1(1), 40-48. Retrieved from https://www.scipublica-

tions.com/journal/index.php/ojer/article/view/71

Received: July 12, 2021

Accepted: October 11, 2021

Published: October 13, 2021

Copyright: $\odot 2021$ by the authors. Submitted for possible open access publication under the terms and conditions of the Creative Commons Attribution (CC BY) license (http://creativecommons.org/licenses /by/4.0/).

\begin{abstract}
This study determined the effect of the combination of conventional lecture and Facebook discussion on the Achievement Pre-service Integrated Science Teachers in an Organic Chemistry course in the College of Education. Two research questions were raised, and one hypothesis was tested. The study adopted a pretest-posttest quasi-experimental research design. A total of 135 PreService Integrated Science Teachers (PSIST) selected using multistage sampling technique were the participants in the study. The main instrument for data collection is Carbon Chemistry Achievement Test, and three other instruments were stimulus instruments. The data collected were analysed using frequency counts, simple percentages, estimated marginal means and analysis of covariance. The result indicates that the PSIST exposed to conventional lecture and Facebook discussion performed better in Organic Chemistry with a significantly higher mean score than their counterparts exposed to traditional lecture alone. It was concluded that integrating Facebook, the leading Web 2.0 communication technologies with teacher education, will ensure better performance of teachers.
\end{abstract}

Keywords: Facebook, Achievement, Preservice Integrated Science Teachers

\section{Introduction}

Information communication technology (ICT) is an aspect of technology used widely for the process of teaching and learning. This is because technology is an established part of the lives of students in this digital age [1]. In a recent year, many educational reforms are occurring all over the world, especially when new innovations and ideas about teaching and learning are to be experimented and implemented [2]. The role of ICT (Information Communication Technology) in science education has been widely justified by several researchers [2].

Internet is an example of communication technology viewed by many educators as a new and potentially powerful teaching medium, but the effectiveness of its use in the classroom depends on the quality of the teaching not the technology $[3,4]$. Web 2.0 technology is an example of communication technology that allows greater collaboration among internet users. Also, it allows users to generate their own content. Previously, data were posted on internet websites and users simply viewed or download the content. Currently, there is a change because users have more input into the nature and scope of web content. According to [5] Web 2.0 application are increasingly embedded in the daily routines of everyday life, particularly for young people in many places and in a variety of different social setting. An example of Web 2.0 application is the social networking site known as Facebook.

Facebook is the most used media networks which provides users with the mix of interpersonal and mass communication capabilities that have not existed before and it places emphasis of mobility and interactivity. It has been established that $95 \%$ of British 
undergraduate students are regularly using social networking sites. The [6] reported that Facebook is the most utilized among the social media in the whole world. [7] revealed that close to ninety-three million Nigerian (51.1\% of the nation's total population) make use of the internet which accounts for $28 \%$ of the internet users in the whole of Africa. In another 2019 report, it was established that fifteen million Nigerian have a Facebook account [7]. Statistics also show that $36 \%$ of Facebook users in Nigeria are between the ages of 1824 years; $37 \%$ of the Facebook users fall between 25-34 years of age.

Although the age range of undergraduates using Facebook is not known with precision in Nigeria but the age range of Facebook users indicates that majority of Facebook users in Nigeria are likely to be in the tertiary institution. Various survey suggest that access to ICT by teachers and learners is increasing dramatically and that the quality of this provision is also improving [8]. Similarly, [9] discuss a number of reasons for using technology in science teaching and learning, including; expediting and enhancing work production; increasing the currency and scope of reference and experience; supporting exploration and experimentation; fostering self-regulation and collaborative learning and finally, improved motivation and engagement.

Unfortunately, it appears that Nigeria is yet to take advantage of the numerous benefits of communication technologies like Facebook in science education. [10] concluded that Facebook is reported to be increasingly used among teachers because the website can be used to gain knowledge, receive feedback and support, while simultaneously sharing teachers' knowledge and expertise. No wonder, after an extensive literature review [11] concluded that Facebook is the most investigated social media when it comes to educational research on social media as a learning tool. As great as the promise of Facebook is, [12] found out in a study majority of students in higher institution do not use Facebook for academic purpose. This is unfortunate because it has been established that $90 \%$ of undergraduate students spend an average of one hour and forty minutes a day on the Facebook site [13].

Facebook can be used for many educational purposes such as: giving the school/institution image and brand [14], sharing educational vision and policy of an institution [15] support class discussions [16] and helping students engage in collaborative learning [11] developing content[16,17] sharing educational resources [1,16], delivering content to expose students to extra-curricular resources [16] and to support self- managed learning [18].

Empirical studies have shown that using Facebook to support class discussion can effectively improve educational outcomes $[19,20]$. In spite of the promise of Facebook in improving students' learning outcomes, it is not without challenges. For example, there are arguments that social media are not designed for educational uses and the learners are susceptible to distraction, most especially if they are young [21]. Other factors such as undeveloped pedagogical skills of teacher in using social media [22], possible distraction of students [11], lack of ICT skills on the part of teacher [11], fear on the part of teachers of using social media to teach [11] and lack of money [23].

These constraints notwithstanding, Facebook has a great value in teaching and learning because it enables teachers to apply social constructivist approaches to teaching [11] . For example, [24] found that while only $41 \%$ of a chemistry class joined the course Facebook group, the number of posts on Facebook were $400 \%$ greater than when other course management system platform was used.

In Nigeria, research on the effect of Facebook as an educational tool on students' learning outcomes appears to be very rare, most especially in the higher education and specifically in colleges of education. For example, [25] determined the effect of social networking site on the engagement and motivation of senior secondary school two students in computer studies. [26] carried out a cross-sectional survey on the effect of Facebook on university undergraduate students' achievement in Chemistry. However, it is important to understand the benefits student can take from the Facebook when it comes to taking learning beyond the classroom in the form of discussion cannot be overestimated [19]. 
Carbon Compounds I is a course that all the pre-service integrated science teachers find very difficult because most of them have the impression that Integrated Science has a discipline should not have a course that will be related to Organic Chemistry among other things. The content of the course covers many things they are familiar with in secondary school. This includes topics like Introduction to Carbon Chemistry, Aliphatic Hydrocarbons, Crude Oil and Coal. The main difference between what the students are learning in the course now is the addition of little A-level content to the O-level they are familiar with. Unfortunately, the performance of pre-service integrated science teachers has been regrettably poor and this often traced to the method of teaching [27]. [28] highlighted the sources of students' difficulty in learning chemistry at the tertiary level where he has taught for over forty years. These sources include science background of the undergraduates; poor secondary school level transition; students' diversity; problems of language science literacy; cognitive level of first year students; prevalence of students' misconceptions; impact of information technology on course delivery and lack of awareness and interest in chemistry education research among lecturers. Furthermore, more often than not, due to constraint of time, resources, electricity and space, most lecturers in higher institutions resort to lecture methods when teaching Chemistry; a method which prevents students to be less involved, which makes them passive, non- thinking, and only play information receiving role. Supplementing formal classroom instruction with Facebook platform is expected to solve the problem of non-usage of digital technology identified by [28] and at the same time make the teacher have informal interaction with the chemistry content learnt in class. The classroom is therefore extended.

Communication technologies are known as providing good results when dealing with difficult concepts in Chemistry [29]. In the face of the constraint of adopting noble teaching strategies, a blend of the conventional teaching strategies and Facebook discussion may offer a good result to pre-service teachers who have difficulty in Organic Chemistry because a blend of traditional instruction method with internet resources has been established to have a positive effect on students' performance [30]. This study therefore determined the effect of using Facebook as a post lecture discussion platform among preservice integrated science teachers on their achievement in a carbon compound I. The approach of this study is an action research of the researcher's classroom experience.

\subsection{Research Question}

1. How many pre-service integrated science teachers joined the Facebook discussion platform?

2. What is the level of participation pre-service integrated science teacher on the Facebook discussion platform?

\subsection{Hypothesis}

There is no significant effect of Pre-service teachers' participation on the Facebook Discussion Platform and their achievement in Carbon Compound I.

\section{Methodology}

\subsection{Research Design}

This study is action research which adopted a pretest-posttest quasi experimental research design. 
Table 1. Research Design

\begin{tabular}{|c|c|c|c|}
\hline Group & Pretest & Treatment & Posttest \\
\hline Group I (expiren) & $\mathrm{O}_{1}$ & Conventional Lecture + Facebook Discussion Platform & $\mathrm{O}_{2}$ \\
\hline Group II(control) & $\mathrm{O}_{3}$ & Conventional Lecture & $\mathrm{O}_{4}$ \\
\hline
\end{tabular}

Table 1 shows that $\mathrm{O}_{1}$ and $\mathrm{O}_{3}$ represent the pretest scores of the pre-service teachers in the experimental and control groups respectively while $\mathrm{O}_{2}$ and $\mathrm{O}_{4}$ represent the posttest scores of the pre-service teachers in the experimental and control groups respectively.

\subsection{Selection of Participants}

The participants of this study were Pre-Service Integrated Science Teachers (PSIST) offering Carbon Compound I in Federal College of Education in Abeokuta Ogun State Nigeria and the researcher is the lecturer in charge of the course. An intact class of 135 PSIST in NCE year two offering ISC 225 Carbon Compound I formed the sample of the Study. Carbon Compound II is a compulsory course for all Integrated Science Pre-service teachers in the college of education selected were the participant. The researcher announced during the first class that there is a Facebook platform for discussion just to extend classroom using technology. The students were asked to send a request to join the platform. The researcher ensures that none of the students were his friend on Facebook during the semester. Hence, participation on the Facebook discussion platform is voluntary, those who choose to join Facebook Chemistry Discussion made up the experimental group (82 PSIST) and those who did not join the Facebook platform is the control group (53 PSIST) during the 2012/2013 academic session. Therefore, the criteria assigning the participant into control and experimental group is joining the Facebook discussion group within a week. It is important to emphasize that the group independence of the normal quasi experiment was not ascertained. The researcher also could not control for instances which the PSIST in the control group interacted with those in the treatment groups.

\subsection{Instrument}

Three instruments used for data collection were:

\subsubsection{Carbon Compound Achievement Test (CCAT)}

This test is made up of twenty multiple-choice questions, ten fill in the gap questions and three essay questions. The test was subjected to the scrutiny of one Ph.D holder in Science Education and one Ph.D holder in Organic Chemistry for content validity. Based on their corrections and recommendation, the required amendments were made on the CCAT. With a three weeks interval, CCAT was administered twice to forty 200 level PSIST in another college of education to determine the reliability. The data obtained from the test-retest method was analysed Cronbach Alpha, the reliability value obtained is 0.82 . The items are theory based and it covers all the content of carbon compound I stated in the background.

\subsubsection{Instructional Guide for the Conventional Teaching Method}

This contains the roles of the Lecturer and the PSIST during the classroom instruction. This is the guideline the researcher followed while teaching in class.

\subsubsection{Facebook Group and Administrator Guide}

This is the platform created for the purpose of instruction and discussion on Carbon Compound I on the Facebook Site, the name of the group is Carbon Compound I. The Guide is to ensure train the administrator to conduct virtual discussion with the aim of 
attaining educational goals. The teacher starts with a poser. For example, why does ethene require just one mole of hydrogen gas to react with to form ethane, but ethyne requires two to form ethane. After this, the learners are expected to provide answers and teacher is not judgmental. Rather, questions and clues that will help objective of the poser to be attained are provided to the learners' responses.

\subsubsection{Procedure}

The first week of resumption was used for administering pretest. The course is a twounit course and two hours of instruction are available to PSIST per week. During the first week, one hour twenty minutes was used for pretest and the next thirty minutes was used to brief the PSIST on how to join the Facebook discussion platform. Students were given just one week to join the Facebook Platform. The treatment started the second week and lasted for 8 weeks. During the treatment, the course lecturer doubled as the administrator of the Facebook discussion platform tagged "carbon compound I". For every lecture in class, the administrator post links, pictures, quiz and materials in line with was taught during the conventional classroom. The students had opportunity to also ask questions on the platform. They can also post anything ranging from questions, new information, and links to an education site to mention a few on the particular topic. The rule agreed upon was no abbreviation or slangs were allowed on the discussion platform.

The Posttest was administered before the final examination in the eleventh week.

The data for the study were analysed using simple, frequency counts, percentages and Analysis of Covariance.

\section{Result}

\subsection{Research Question one}

How many pre-service integrated science teachers joined the Facebook discussion platform?

Table 2. Percentage of Pre-service Integrated Science Teachers

\begin{tabular}{|c|c|}
\hline Treatment & Frequency/Percentage \\
\hline Lecture + Facebook sDiscussion & $82(60.7 \%)$ \\
\hline Lecture & $53(39.3 \%)$ \\
\hline Total & $135(100 \%)$ \\
\hline
\end{tabular}

Table 2 shows that exactly $60.7 \%$ of the PSIST participated and joined the Facebook. This is implying that six out of ten of PSIST joined Carbon Compound I. Hence, more than half of the PSIST were willing to join the Facebook platform. Although the study did not investigate the constraint (such as lack of smart phone and data) that could be traced to the PSISTs who did not join the platform within the stipulated time. However, the PSIST in the college had access to an hour of internet usage every day in the college ICT center. This is very instructive because several students who do not use the opportunity for learning purpose choose to do so. This is an indication that it is not all millennials or digital natives are willing to use Facebook for learning. Howbeit many are willing to use it.

\subsection{Research Question two}

What is the level of participation of the pre-service integrated science teacher on the Facebook discussion Platform? 


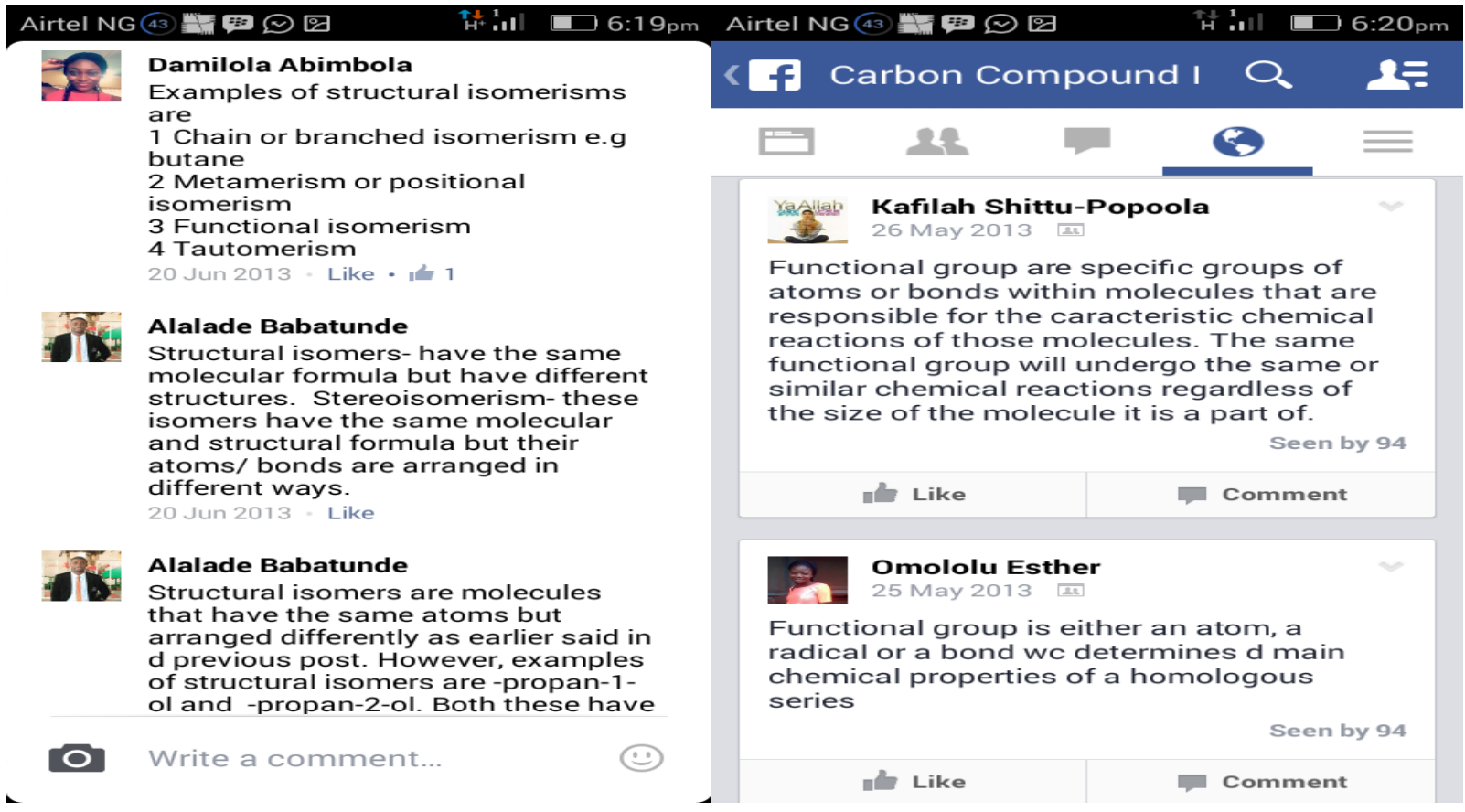

Figure 1. A screen shot of students' discussion on the concept of Isomerism

The result showed that 82 of the PSIST who joined the Facebook discussion platform on Carbon Compound One. However, in terms of active participation (posting links and being part of a discussion) only twenty-two PSIST actually posted on the wall. The rest only viewed and liked the post. This means that $26.82 \%$ of the students who joined Facebook platform wrote a comment on the Facebook platform for Carbon Compound I.

The nature of the comments are answers to instructor posers, questions seeking clarification and narration of examples that are beyond the one stated. Some stated other things they read online concerning the content. This implies that when some students go on Facebook platform of Carbon Compound I, they search for some information on the content being discussed on some search engine on the internet. More importantly, there were more teacher-student and student-student interaction in the Facebook group.

\subsection{Hypothesis Testing}

There is no significant effect of Pre-service teachers' participation on the Facebook Discussion Platform and their achievement in Carbon Compound I.

Table 3. Analysis of Covariance of Pre-Service Integrated Science Post-Test Score by Treatment

\begin{tabular}{|c|c|c|c|c|c|c|}
\hline Source & $\begin{array}{c}\text { Type III Sum of } \\
\text { Squares }\end{array}$ & Df & Mean Square & F & Sig & $\begin{array}{c}\text { Partial Eta } \\
\text { Squared }\end{array}$ \\
\hline $\begin{array}{c}\text { Corrected } \\
\text { Model }\end{array}$ & $1808.126^{\mathrm{a}}$ & 2 & 904.063 & 29.330 & .000 & .308 \\
\hline Intercept & 5938.478 & 1 & 5938.478 & 192.656 & .000 & .593 \\
\hline Pretest & 1731.363 & 1 & 1731.363 & 56.169 & .000 & .299 \\
\hline treatment & 141.944 & 1 & 141.944 & 4.605 & .034 & .034 \\
\hline Error & 4068.808 & 132 & 30.824 & & & \\
\hline Total & 610285.000 & 135 & & & & \\
\hline $\begin{array}{c}\text { Corrected } \\
\text { Total }\end{array}$ & 5876.933 & 134 & & & & \\
\hline
\end{tabular}


The Table 3 indicates that the treatment has a significant effect on Pre-service Integrated Science Teachers' post-test achievement score in Carbon Compound One $\left[\mathrm{F}_{(2,132)}=4.60:(\mathrm{p}=0.034<0.05): \eta^{2}=0.034\right]$. This implies that the treatment had a significant effect with an effect size of $3.4 \%$ and the null hypothesis is rejected.

Table 4. Estimated Marginal of Post test Scores

\begin{tabular}{|c|c|c|}
\hline Treatment & $\mathbf{N}$ & Mean \\
\hline Lecture + Facebook Discussion & 82 & 68.19 \\
\hline Lecture & 53 & 66.08 \\
\hline
\end{tabular}

Table 4 indicates that PSIST exposed to Lecture and Facebook (68.19) had a higher mean score than those exposed to lecture alone (66.08) in Carbon Compound One. This implies that the significant effect is attributed to the score of those exposed to conventional lecture and Facebook discussion.

\section{Discussion}

The findings of the study established that when pre-service integrated science teacher are taught organic Chemistry using Facebook discussion as a supplement to conventional instruction, their achievement is better than being taught only through the conventional lecture method. This is probably because the pre-service teachers are likely to go beyond the discussion and learn things related to organic chemistry through search engines. This will make them master the concept that will be otherwise challenging; because of the voluminous nature of Organic Chemistry which the learners cannot master through rote memorisation. The efficacy of the treatment in this study may also be traced to the fact that use both mobile and web-based technologies allow students have access to additional information on the go, most especially in places they may not carry their text or notebooks to. However, the dependence of treatment and control groups is a theoretical threat to the validity of these findings because those in control groups could have probably participated in the treatment. Since it is action research, it was impossible to control for any PSIST in the control group who could have been a part of the experimental group through the mobile device of another classmate. It is also possible that only PSIST with high academic ability joined the Facebook discussion platform. If the latter were true, the significance difference observed might be traced to the fact that the students who did not join the Facebook platform are the weak ones and even if this experiment were to be between the weak students in class and the academically strong ones, the same result will be obtained. Howbeit, this does not invalidate the fact that the nature of contribution of the students in the treatment group will facilitate meaningful learning and over-learning. There is also a continuous reflection that aids cognitive conflict and resolution of the concepts that may not be clear to the PSIST. The findings of this study is in accord with the findings of [31] which revealed that a blend of face-to-face classroom sessions and on line learning environment significantly improves Turkish teacher trainee cognitive flexibility and self regulated learning skills in a course titled IT and Ethics a course in computer education. The findings of this study are in line with the findings of [32] that use of Facebook for instructional purpose significantly increased the university student's collaboration and engagement foundation information technologies course. The findings of this study are also in agreement with the findings of [33] which showed that teaching English language to students offering business communication course in technical university in Taiwan.

This study also showed that more students were willing to join Facebook discussion platform. This implies that if the Facebook is introduced to the learners, majority of them will embrace it as an educational tool. This is in line with the findings of [35] that incor- 
porating Facebook into the learning resources of university courses may impact upon student satisfaction of course delivery, as they are able to integrate academic requirements with a social networking platform that they are familiar and highly engaged with.

The result also showed that many of the pre-service teachers who joined the discussion platform were passive during the discussion. Although it is important to note that many students who were passive in face-to-face classroom were active in Facebook. This finding is in accord with the assertion of [24] students fearlessly interact with new information when involved in virtual discussion.

The findings of this study is not without a limitation because the significant mean difference observed between experimental and control groups is (2.01). This difference may not be directly traced to the cognitive gain of the PSIST in the experimental group. Rather it may have a link with some psychological construct such as interest, self efficacy and confidence they gained which were not investigated in this study that could also promote the cognitive gain.

\section{Conclusion}

It was concluded that Facebook as a discussion platform along with conventional lecture is more effective than conventional lecture method alone.

\section{Recommendation}

Since teachers end up teaching their pupils or students the way they were taught, it is vital to integrate technology like Facebook in their preparation so as to ensure that when they teach, they will also take advantage of such communication technology. It is also important for researchers in Nigeria, to determine the impact of other social media (Twitter,Youtube et.c) on students' and pre-service teachers' performance in various science subjects. In-service teachers should be sensitised and trained so that they can adopt the integration of Web 2.0 technologies like Facebook in chemistry classroom and other science subjects. The current curriculum of educational technology of preservice teacher in Nigeria is yet to provide the required learning experiences that will make develop preservice teachers' expertise to use Web 2.0 communication technologies for instructional purposes. Therefore, there is a need for a review the learning experiences in educational technology. Adequate communication technologies, equipment and materials should be provided by government and stakeholder. Preservice teacher education, should also ensure that the subject teaching method courses contain learning experiences that will develop their skills of using web 2.0 technology for the promise it holds.

\section{References}

[1] Prescott, J. (2014) How Professors are using Facebook to Teach. Washington Post July 12014.

[2] Daud,M.Y., Halim, L., Zain, M.F.M., Buang,N.A.Embi,M.A.(2010)Toward Integrated ICT Classroom for Effectives Teaching and Learning Science: Issues and Constrains from Malaysian Schools Context. In M.F. Taşar \& G. Çakmakcı (Eds.), Contemporary science education research: teaching(pp. 225-230). Ankara, Turkey: Pegem Akademi.

[3] Madge, C., Meek, J.,Wellens, J., \& Hooley, T. (2009). Facebook, social integration and informal learning at university: "It ismore for socialising and talking to friends about workthan for actually doing work". Learning, Media and Technology, 34(2), 141155.

[4] Adam, D., Carlson, H., \& Hamm, M. (1990). Cooperative learning and educational media:Collaborating with technology and each other. Englewood Cliffs, NJ: Englewood Technology Publications

[5] Jonasson, D. H. (1994). Thinking Technology: Towards a constructivist design model. Educational Technology, 34, 34-37.

[6] Goktalay, S. (2013). Challenges facing higher education: Faculty's concerns about technologies of social media. International Journal of Continuing Engineering Education and Life-Long Learning, 23, 67 -90. doi:10.1504/ IJCEELL.2013.051767

[7] Miniwatts Incorporated (2016) Africa 2015 Population and Internet Users Statistic. InternetWorld Usage.

[8] Ofsted (2002). ICT in schools: effect of government initiatives-secondary science. HMI 715. E-publication website:www.ofsted.gov.uk

[9] Osborne, J.\& Hennessy, S. (2003) Literature review in Science Education and the Role of ICT: Promise, Problems, Future Directions. Futurelab Series. Report 6 
[10] Trust, T. (2012). Professional learning networks designed for teacher learning. Journal of Digital Learning in Teacher Education, 28, 133-138. doi:10.1080/21532974.2012.10784693

[11] Van Acker, F., Van Buuren, H., Kreijns, K., \& Vermeulen, M. (2011). Why teachers use digital learning materials. Educational Information Technology, 18, 495-51.

[12] Adaja, T.A. and Ayodele, F. (2013) Nigerian youths and social media harnessing the potentials for academic excellence. Singaporian Journal of Business Economics and Management Studies. 1(6), 1-16.

[13] Junco, R. (2012). The relationship between frequency of Facebook use, participation in Facebook activities, and student engagement. Computers E Education, 58(1), 162-171.

[14] Bélanger, C. H., Bali, S., \& Longden, B. (2014). HowCanadian universities use social media to brand themselves. Tertiary Education and Management, 20, 14.

[15] Beemt, A. V., Thurlings, M. \& Willems, M. (2020) Towards an understanding of social media use in the classroom: a literature review, Technology, Pedagogy and Education, 29:1, 35-55, DOI: 10.1080/1475939X.2019.1695657

[16] Manca, S., \& Ranieri, M. (2013). Is it a tool suitable for learning? A critical review of the literature on Facebook as a technologyenhanced learning environment. Journal of Computer Assisted Learning, 29(6), 487-504.

[17] Chen, B., \& Bryer, T. (2012) Investigating instructional strategies focusing social media In formal and informal learning. The International Review of Research in Open and Distance Learning, 13, 87 -104. doi:10.19173/irrodl.v13i1.1027.

[18] Evans, C., \& Kozhevnikov, M. (2013). Styles of practice in higher education: Exploring approaches to teaching and learning. London: Routledge.

[19] McCarthy, J. (2010). Blended learning environments: Using social networking sites to enhance the first year experience. Australasian Journal of Educational Technology, 26. doi:10.14742/ajet.1039

[20] Hurt, N. E., Moss, G. S., Bradley, C. L., Larson, L. R., Lovelace, M. D., Prevost, L. B. (2012). The "Facebook" effect: College students' perceptions of online discussions in the age of social networking. International Journal for the Scholarship of Teaching and Learning, 6(2), 1-24.

[21] Kuiper, E., Volman, M., \& Terwel, J. (2005). The web as an information resource in K-1 education: Strategies for supporting students in searching and processing information. Review of Educational Research, 75, 285-328. doi:10.3102/00346543075003285

[22] Hew, K., \&Cheung, W. (2013). Use of web 2.0 technologies inK-12 and higher education: The search for evidence-based practice. Educational Research Review, 9,47 -64. doi:10.1016/j.edurev.2012.08.001

[23] Cox, D., \& McLeod, S. (2014a). Social media marketing and communications strategies for school superintendents. Journal of Educational Administration, 52, 850-868. doi:10.1108/JEA-11-2012-0117

[24] Schroeder, J and Greenbowe, T. J. (2009) "The Chemistry of Facebook: Using Social Networking to Create an Online Community for the Organic Chemistry Laboratory," Innovate: Journal of Online Education: 5(4), 3.

[25] Fatokun, K.V. (2019) Effect of Social Media on Undergraduate Students' Achievement and Interest in Chemistry in the North Central Geopolitical zone in Nigeria. International of Journal of Science and Technology Educational Research 10 (20) 9-15

[26] Zakana, M.E.\& Fomsi, E. (2019) Effect of Social Networking Sites on Students' Engagement and Motivation in Computer Science in Bayelsa State Nigeria. European Scientific Journal 15 (5); 132-145

[27] Cardilleni, L. (2012) Chemistry: Why the Subject is Difficult? Educ. quím., publicado en línea el 242 de abril de 2012

[28] Treagust, D., Duit, R., and Nieswandt, M. (2000) Sources of Students Difficulties in Learning Chemistry. Educacion, Quimica,11 (2), 228-235

[29] Paiva, J and Fonseca,S. (2009).The Challenges of Using ICT to Cross Boundaries in the Teaching of chemical Equilibrium Portuguese Participation in Crossnet project. In M.F. Taşar \& G. Çakmakc1 (Eds.), Contemporary science education research: teaching (pp. 269-272). Ankara, Turkey: Pegem Akademi.

[30] Learning Technology Centre (2009) Advantages of Blended Learning. Retrieved on the $16^{\text {th }}$ of June 2009 from http://hybrid.uwm.edu

[31] Shuja, A., Qureshi, I. A., Schaeffer, D. M., \& Zareen, M. (2019). Effect of m-learning on students' academic performance mediated by facilitation discourse and flexibility. Knowledge Management \& E-Learning, 11(2), 158-200. https://doi.org/10.34105/j.kmel.2019.11.009

[32] Cobanoglu, and Yurdakul, B. (2014) The effect of Blended Learning on Students' Achievement, Perceived Cognitive Flexibility levels and Self-Regulated Learning Skills. Journal of Education and Practice 5 (22),1-22 Retrieved on $17^{\text {th }}$ June, 2016 from http//www.iiste.org

[33] Mbodila, M., Ndebele, C. and Muhandji, K. (2014) The Effect of Social Media on Student's Engagement and Collaboration in Higher Education: A Case Study of the Use of Facebook at a South African University. Journal of Communication,5 (2) ,115-125

[34] Shih,R. (2013) Effect Of Using Facebook to Assist English for Business Communication Course Instruction. The Turkish Online Journal of Educational Technology - January 2013, volume 12 Issue 1

[35] Irwin, C., Ball, L., Desbrow, B. \& Leveritt, M. (2012). Students' perceptions of using Facebook as an interactive learning resource at university. Australasian Journal of Educational Technology, 28(7), 1221-1232. 